\title{
Offita barna
}

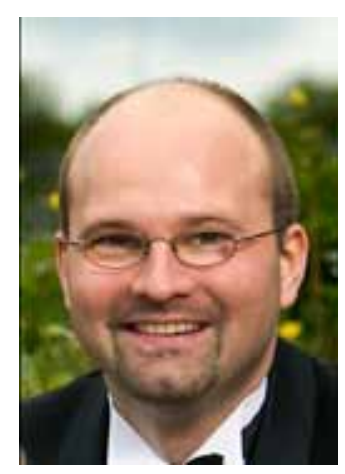

Tryggvi Helgason barnalæknir

tryggvihe@simnet.is

Höfundur er barnalæknir í Domus Medica með offitu barna sem sérsvið.

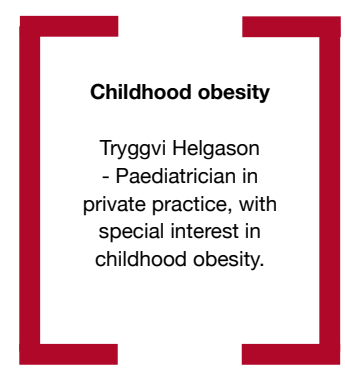

Offita barna er vaxandi vandamál í hinum vestræna heimi. Prátt fyrir að mikil vakning hafi orðið í pessum málum hefur ekki tekist að snúa próuninni við síðastliðin ár. Ef pað tekst ekki mun pað hafa mikil áhrif á lífsgæði og lífslíkur pjóða.

Hér á Íslandi eigum við tölur um próun pyngdar 9 ára íslenskra skólabarna á 20. öld sem Brynhildur Briem tók saman. ${ }^{1}$ Pær sýna svo ekki verður um villst að offita barna hefur farið hratt vaxandi hér frá pví á áttunda áratugnum. Samkvæmt Lýðheilsustöð (2009) mælast 21,3\% íslenskra 5-15 ára barna of pung og rúmur fjórðungur peirra, eða 5,5\% barna á Íslandi, mælast of feit. Petta hlutfall hefur farið hratt hækkandi á síðustu áratugum. Pegar hlutfallið er umreiknað í fjölda barna kemur í ljós að um 2650 börn á Íslandi eru of feit. Petta er stór hópur og pörf fyrir markviss inngrip.

Í pessu tölublaði Læknablaðsins eru niðurstöður mælinga Kristjáns Pórs Magnússonar og félaga á hreyfingu 9 og 15 ára íslenskra skólabarna teknar saman. ${ }^{2}$ Pær sýna að mikill meirihluti íslenskra barna, mælt á hlutlægan hátt, hreyfir sig minna en ráðlegt er til að viðhalda heilsunni. Pau börn sem hreyfðu sig minna, reyndust vera með meiri fitu undir húð en pau sem hreyfðu sig meira. Niðurstaða peirra er að íhlutunar sé pörf til að auka hreyfingu barna í skólum á Íslandi. Pegar horft er til aukningar á offitu barna hérlendis er eðlilegt að draga pá ályktun. Vissulega er í mörgum tilvikum pörf á átaki í að bæta mataræði og minnka neyslu á orkuríkum og næringarsnauðum mat og drykk. Раð hefur hins vegar frá alda öðli verið talið merki um hreysti unga fólksins að pað sé duglegt að hreyfa sig. Enda hefur verið sýnt að ef börn eru í réttu umhverfi liggur í eðli peirra að hreyfa sig. Pví er rannsóknin sem kynnt er í pessu tölublaði mikilvægt innlegg og góð hvatning fyrir pá sem vinna nú pegar að aukinni hreyfingu barna. Einnig eru petta skýr skilaboð til yfirvalda um hvar megi spara og hvar skuli bæta við fjármunum.

Læknum er vel ljós sú hætta sem fylgisjúkdómar offitunnar bera með sér. Má par nefna sykursýki, háan blóðprýsting og fitulifur. Rannsókn á indiánum í Arizona sýnir að áhrif fylgisjúkdóma byrja strax á barnsaldri. ${ }^{3}$ Börn sem pjáđust af offitu við 11 ára aldur voru tvöfalt líklegri til að deyja fyrir 55 ára miðað við pá sem voru grannir, ef ytri orsakavaldar, svo sem slys, eru dregin frá. Pótt erfitt sé að alhæfa út frá slíkri erlendri rannsókn eru sterkar líkur á að hið sama eigi við um Íslendinga og að of mikil fita allt frá barnsaldri auki álag á kerfi líkamans og valdi hættulegum fylgisjúkdómum í framtíðinni.
Tíðni pessara sjúkdóma mun aukast hratt á næstu árum ef ekkert er að gert. Svo hratt að ævilíkur kynslóðarinnar sem nú vex úr grasi gæu verið styttri en peirrar sem ól hana af sér. Petta er pveröfugt við pá próun sem varð á síðustu öld á lífsgæðum og ævilíkum. ${ }^{4}$ Pegar jafn örar breytingar verða á próun heilsu heilla kynslóða er eðlilegt að álykta að vandann sé að finna í próun samfélags okkar á síðustu áratugum.

Læknar hafa í sögulegu samhengi haft forgöngu um breytingar á samfélaginu í átt að heilbrigðari lífsháttum. Má par nefna baráttu gegn ungbarnadauða, bólusetningar og pegar fátækum börnum var gefin mjólk í skólum.

Vandi okkar í dag snýr hins vegar frekar að ofgnótt en skorti eins og á uppvaxtarárum lýðveldisins. Ástríður Stefánsdóttir siðfræðingur velti í fróðlegum fyrirlestri upp peirri spurningu hvort pað væru kannski ekki peir einstaklingar sem væru of feitir, sem væru vandamálið, heldur sýndu peir merki pess að samfélagið okkar ætti í vanda. Pað hlýtur að minnsta kosti að vera okkur umhugsunarefni pegar gera parf fjölda aðgerða á ári til pess að peir sem verst eru staddir geti búið í samfélagi okkar án pess að pjást af fylgisjúkdómum offitu.

Pegar nýtt heilbrigðisvandamál birtist, eins og offita barna hefur gert á síðustu árum, parf að bregðast við pví og læknar geta verið par í forystuhlutverki. Stöðugt meiri pekking byggist upp á pví hvað hægt sé að gera til að snúa próuninni við. Hér á landi er stækkandi hópur vísindamanna að leita leiða til að auka hreysti pjóðarinnar eins og greinin í blaðinu er gott dæmi um. Nú er pví mikilvægt að læknar, vísindamenn, heilbrigðisstarfsmenn, stjórnmálamenn, foreldrar og aðrir peir sem láta sér annt um heilsu íslenskra barna taki höndum saman og stýri samfélaginu af peirri braut sem leiðir til aukinnar offitu og inn á braut hreysti og heilbrigðari lífsstíls.

\section{Heimildir}

1. Briem B. Breytingar á hæð og pyngd 9 ára skólabarna í Reykjavík 1919-1998. Meistaraprófsritgerð læknadeild Háskóla Íslands, ágúst 1999.

2. Magnússon KP, Arngrímsson SÁ, Sveinsson P, Jóhannsson E. Líkamshreyfing 9 og 15 ára íslenskra barna í ljósi lýdheilsumarkmiða. Læknablaðið 2011; 97: 75-81.

3. PW Franks, Hanson RL, Knowler WC, et al. Childhood obesity, other risk factors, and premature death. NEJM 2010; 362: 485-93.

4. Olshansky SJ, Passaro DJ, Hershow RC, et al. A potential decline in life expectancy in the United States in the 21st Century. N Engl J Med 2005; 352: 1138-45. 